\title{
Expression of SOD transgene in pepper confer stress tolerance and improve shoot regeneration
}

\author{
Kiriaki Chatzidimitriadou \\ School of Agriculture \\ Aristotle University of Thessaloniki \\ Thessaloniki, Greece \\ Irini Nianiou-Obeidat \\ School of Agriculture \\ Aristotle University of Thessaloniki \\ Thessaloniki, Greece \\ Panagiotis Madesis \\ School of Agriculture \\ Aristotle University of Thessaloniki \\ Thessaloniki, Greece
Rafael Perl-Treves
Department of Life Sciences
Bar-Ilan University
Ramat Gan, Israel
Athanasios Tsaftaris*
School of Agriculture
Insitute of Agrobiotechnology
Thessaloniki, Greece \\ Aristotle University of Thessaloniki \\ E-mail: tsaft@agro.auth.gr
}

Financial support: Grant from Greek Secretary for Research and Technology to A.S.T.

Keywords: Capsicum annum L., SOD, MV, drought stress, regeneration.

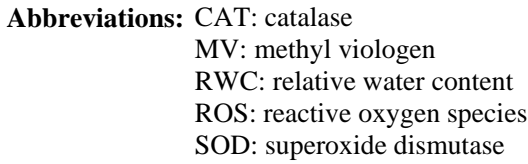

Abbreviations: CAT: catalase

MV: methyl viologen

RWC: relative water content

ROS: reactive oxygen species

SOD: superoxide dismutase

The objective of this work was to study the stress tolerance and regeneration capability of transgenic pepper plants carrying a sod gene, encoding a tomato chloroplast-localized $\mathrm{Cu} / \mathrm{Zn}$ SOD protein. The expression of the sod gene was confirmed by enzymatic staining following polyacrylamide gel electrophoresis (PAGE), revealing a 'novel' band, which could represent a heterodimeric enzyme. Transgenic $T_{1}$ and $T_{2}$ progeny plants were exposed to different oxidative stresses including Methyl viologen (MV) and drought and found to have an increased resistance to oxidative damage. Furthermore, the SOD carrying transgenic pepper plants showed increased levels of regeneration efficiency compared to the wild type pepper plants. Pepper is a recalcitrant species in terms of its in vitro regeneration ability but it could be extremely useful for the development of pharmaceuticals. This approach enables the extent use of pepper for genetic transformation and the production of high valuable products in plants particularly the large fruit varieties.

Active oxygen species were considered to be important damaging factors in plants exposed to stressful environmental conditions such as drought (Badawi et al. 2004), and pathogen attack (Tertivanidis et al. 2004) as well as to chemical treatment such as paraquat (Perl et al. 1993). Plant antioxidant defense systems include enzymes such as superoxide dismutase (SOD), catalase (CAT) and ascorbate peroxidase (APX) (Apel and Hirt 2004; Mancini et al. 2006). The SOD enzyme constitutes a component of the first line of cellular defense against oxidative stress by early scavenging superoxide radicals and converting them

*Corresponding author 
to hydrogen peroxide (Perl-Treves and Galun, 1991). Transformation of many plant genera for useful traits, such as oxidant-resistance, is now routine (Perl-Treves and Galun, 1991; Perl et al. 1993; Tertivanidis et al. 2004). More recently the studies were extended in important vegetable crops where a sod tomato gene was cloned into a pepper plant (Zambounis et al. 2002).

The active oxygen species hydrogen peroxide $\left(\mathrm{H}_{2} \mathrm{O}_{2}\right)$ was viewed mainly as a toxic cellular metabolite but, it became evident that it has multiple roles in plants. It can function as a signaling molecule that mediates responses to various stimuli in plants (Neill et al. 2002). Moreover, $\mathrm{H}_{2} \mathrm{O}_{2}$ modulates the expression of various genes, including those encoding antioxidant enzymes and modulators of $\mathrm{H}_{2} \mathrm{O}_{2}$ production (Neill et al. 2002). In addition, a microarray study showed that the expression of $1-2 \%$ of genes was altered in $\mathrm{H}_{2} \mathrm{O}_{2}$-treated Arabidopsis cultures and particular genes encoding antioxidant enzymes were upregulated (Desikan et al. 2001).

Recently the involvement of $\mathrm{H}_{2} \mathrm{O}_{2}$ and SOD in regeneration of plants has also been proposed (Cui et al. 1999; Luo et al. 2001; Papadakis et al. 2001; Tian et al. 2003; Libik et al. 2005; Zheng et al. 2005).

Active oxygen species may also have a positive role in plant growth and development (Tian et al. 2003). A dual role for $\mathrm{H}_{2} \mathrm{O}_{2}$ in the regeneration of protoplasts has also been shown (De Marco and Roubelakis-Angelakis, 1996). Furthermore, it has been reported that the cytosolic $\mathrm{Cu} / \mathrm{Zn}$ SOD was induced in regenerating tobacco protoplasts but not in the recalcitrant grapevine protoplasts (Papadakis et al. 2001), which supports the hypothesis that SOD is involved in plant morphogenesis.

The aim of this work was to investigate the expression and behavior of transgenic red pepper type "Florinis" plants carrying a tomato $\mathrm{Cu} / \mathrm{Zn}$ SOD gene under different stressesand investigate the potential regeneration efficiency of the SOD over-expressing transgenic plants.

\section{MATERIALS AND METHODS}

\section{Plant material}

The primary $\mathrm{T}_{0}$ transgenic plants expressing tomato chlCu/Zn SOD were produced by Agrobacterium-mediated transformation of Capsicum annum L., red pepper type "Florinis" (Zambounis et al. 2002). $\mathrm{T}_{0}$ plants were obtained and the $T_{1}$ were selected for further research.

$\mathrm{T}_{1}$ and $\mathrm{T}_{2}$ seeds were surface-sterilized by soaking in $2.5 \%$ NaOCI supplemented with a few drops of TritonX $100 \%$ (Merck)/100 ml solution for 10 - 15 min followed by 3 washes in sterile water. The seeds were dried and placed on half-strength MS medium (Murashige and Skoog, 1962) agar-solidified $(0,8 \% \mathrm{w} / \mathrm{v})$, the $\mathrm{pH}$ was adjusted at 5.8 with $\mathrm{KOH}$ or $\mathrm{NaOH}$ before autoclaving without antibiotics in order to determine the germination ability or with

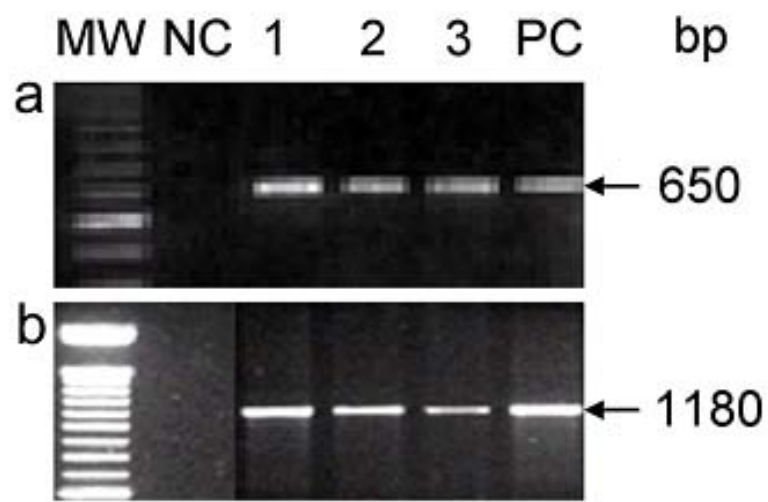

Figure 1. PCR analysis of kanamycin resistant T1 and T2 progeny of transgenic pepper plants. (a) PCR amplification of the nptll gene region. MW: marker, NC: negative control of non-transgenic pepper plant, 1-3: $\mathrm{T}_{1}$ transgenic pepper plants, PC: positive control of pepper transgenic plant. (b) PCR amplification of the 35S-nos region. MW: marker, NC: negative control of non-transgenic pepper plant, 1-3: $\mathrm{T}_{1}$ transgenic pepper plants, PC: positive control of pepper transgenic plant.

Kanamycin (100 mg. $\left.\mathrm{l}^{-1}\right)$ for screening resistant $\left(\operatorname{Kan}^{\mathrm{R}}\right)$ seedlings. The seeds were germinated under darkness at $25^{\circ} \mathrm{C}$. All cultures were kept in growth chambers at $25 \pm$ $2^{\circ} \mathrm{C}$, with a photo period of $16 \mathrm{hrs} / 8 \mathrm{hrs}$ light (intensity of 2.500 - 4.000 Lux) / dark, respectively.

\section{PCR verification of $T_{1}$ and $T_{2}$ transgenic pepper plants}

The presence of the transgenes in kanamycin resistant plants was initially verified via PCR to confirm the presence of the nptII and the chimeric sod gene. DNA was extracted using the DNeasy Plant mini kit (Qiagen). For the PCR reaction 20 ng of DNA were added to the PCR mixed which consists of $1.5 \mathrm{mM} \mathrm{MgCl}_{2}, 1 \mathrm{X}$ buffer (Gibco BRL), $0.2 \mathrm{mM}$ deoxyribonucleotide triphosphate (dNTPs), 1 unit of Taq polymerase, $0.5 \mu \mathrm{M}$ of each primer in a final volume of $12.5 \mu \mathrm{L}$.

Two rounds of PCR screening were performed. In the first round, plants were screened for the presence of a $650 \mathrm{bp}$ band which corresponds to the nptII gene. The sequences of the primers used were Forward: 5'-GAG GCT ATT CGG CTA TGA CTG-3' and Reverse: 5'-ATC GGG AGC GGC GAT ACC GTA-3'. The PCR program included 4 min at $94^{\circ} \mathrm{C}$, then 30 cycles of $94^{\circ} \mathrm{C}$ for $1 \mathrm{~min}, 59^{\circ} \mathrm{C}$ for $1 \mathrm{~min}, 1$ min at $72^{\circ} \mathrm{C}$, followed by a final extension at $72^{\circ} \mathrm{C}$ for 1 $\min$.

In the second round, plants were screened for the amplification of a $1180 \mathrm{bp}$ band, which corresponds to the $900 \mathrm{bp} \mathrm{Cu/} \mathrm{Zn} \mathrm{SOD} \mathrm{gene} \mathrm{and} \mathrm{a} \mathrm{fragment} \mathrm{of} \mathrm{Ca} \mathrm{MV} \mathrm{35S}$ promoter and nos terminator. The sequences of the primers used were Forward: 5'-GGA GCA TCG TGGA AAA AGA AGA C-3' and Reverse: 5'-TTA TCC TAG TTT GCG CGC TA-3'. The PCR reactions were run at $94^{\circ} \mathrm{C}$ for 5 


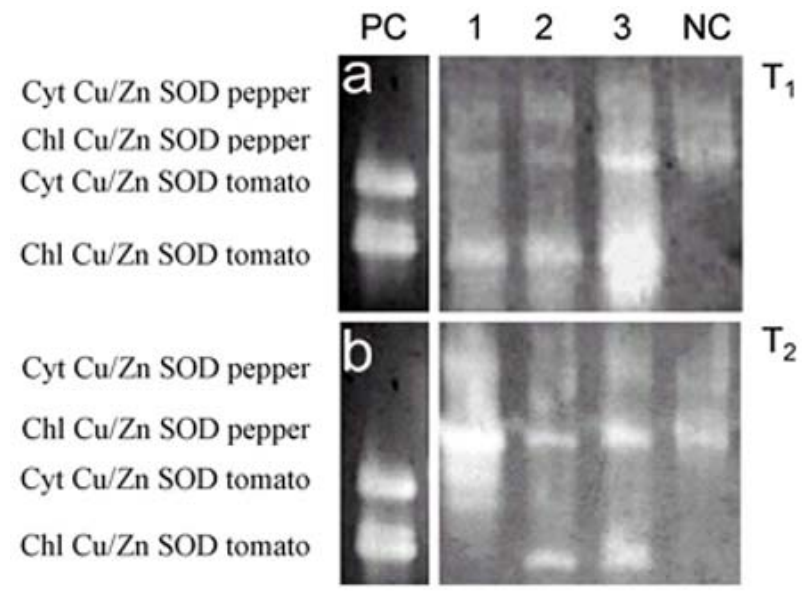

Figure 2. SOD isozyme patterns of protein extracts from non-transgenic pepper, tomato and transgenic $T_{1}(a)$ and $T_{2}$ (b) pepper plants. The non-denaturing polyacrylamide gel was loaded with $40 \mu \mathrm{g}$ protein per slot and (negatively) stained with riboflavin-nitroblue tetrazolium. PC: control from non- transgenic tomato plant, 1-3: $\mathrm{T}_{1}$ and $\mathrm{T}_{2}$ transgenic pepper plants, $\mathrm{NC}$ : negative control of non -transgenic pepper plant.

min, then 30 cycles of $94^{\circ} \mathrm{C}$ for $40 \mathrm{sec}, 57^{\circ} \mathrm{C}$ for $30 \mathrm{sec}$, $72^{\circ} \mathrm{C}$ for $1 \mathrm{~min}$, followed by a final extension at $72^{\circ} \mathrm{C}$ for 3 $\min$.

\section{SOD enzyme electrophoresis}

Leaves from $T_{1}, T_{2}$ transgenic and untransformed pepper plants (wt) were homogenized in a buffer consisting of a glycine buffer, $\mathrm{pH} 7.4$, containing polyvinylpyrrolidone (p6755). After centrifugation (5 min, 14,000 rpm), the clear supernatant was assayed for protein content (Bradford, 1976), and $40 \mu \mathrm{g}$ of protein were loaded on a nondenaturing 9\% polyacrylamide gel with a 3\% stacking gel (Laemmli, 1970). The gel was run at $4^{\circ} \mathrm{C}(100$ Volt) and stained for SOD by the riboflavin-nitroblue tetrazolium as described (Beauchamp and Fridovich, 1971).

\section{MV application}

The herbicide Methyl viologen (MV) (1.1 dimethyl-4.4bipyridinium chloride, Sigma, USA), was used to generate free radicals and oxidative stress in cells during illumination. Prior to the experiment, we tested untransformed pepper plants with a range of $\mathrm{MV}$ solutions $0-0.5 \times 10^{-3} \mathrm{M}$ and found $0.25 \times 10^{-3} \mathrm{M} \mathrm{MV}$ to be the optimal concentration in order to test the transgenic plants for tolerance to the herbicide (data not shown). Stem cuttings from greenhouse-grown untransformed red pepper type "Florinis" and $\mathrm{T}_{1}$ and $\mathrm{T}_{2}$ transformed plants, with fully expanded mature leaves, were placed in tubes containing 50 $\mathrm{ml}$ of $0.25 \times 10^{-3} \mathrm{M} \mathrm{MV}$, according to the procedure of Perl et al. (1993). After 16 hrs incubation, the MV was discarded and the test-tubes were washed and filled with tap water. Clear paraquat-damage symptoms were noticed after 48 hrs exposure to constant illumination at light intensity of $45 \mu \mathrm{Em}^{2} \mathrm{~s}^{-1}$. Oxidative damage was assessed visually. All experiments were repeated at least twice.

\section{Water-deficit stress}

In order to investigate the drought stress tolerance of the $T_{1}$ and $\mathrm{T}_{2}$ transgenic pepper plants and untransformed control, plants were grown in $5 \mathrm{lt}$ pots in a controlled environment. In the experiment, the fifth leaf from the top was sampled, taken from 3 independent transgenic plants and each generation $T_{1}, T_{2}$ and from control plants. The state of the drought - stressed plants was expressed by Relative Water Content (RWC) defined as: 100 x (actual leaf weight-dry weight) / (hydrated weight-dry weight) according to PerlTreves and Galun (1991). From each leaf, 12 leaf discs were cut and the RWC was measured. In order to measure the leakage of electrolytes, 8 leaf discs were used. A normal irrigation regime was maintained until the plants were exposed to drought for fourteen days. Following this method, after sampling and weighing (actual weight), leaves were immersed for 20 hrs in distilled water, blotted and weighed (hydrated weight). For dry weight determination leaves were dried overnight in a $70^{\circ} \mathrm{C}$ oven. Leakage of electrolytes from leaf discs was used as a parameter of membrane damage. Leaf discs were cut as before from soil grown plants, rinsed and immersed for 22 hrs in $3 \mathrm{ml}$ of distilled water. The electrolyte leakage (\%) was measured with a Consort C831 (Belgium) conductivity metre and was defined as: $100 \mathrm{x}$ (electrolyte leakage before boiling / electrolyte leakage after boiling). Three replications were used in every experiment. The data were tested by analysis of variance (ANOVA) at $\mathrm{p}<0.001$.

\section{In vitro regeneration ability}

For the regeneration experiment, 7 - 10 days old seedlings were used as explant donors from three independent $T_{1}$, three independent $T_{2}$ sod transgenic plants and untransformed (wt) control pepper plants. Specifically, we used 45 hypocotyls per each independent transgenic plant and for each control. The shoot regeneration regime was as described before (Zambounis et al. 2002). The regeneration was estimated after 2 months. Regeneration frequency was calculated as the number of regeneration explants per total number of cultured explants. Three replications were used in the experiment. The results were analysed by analysis of variance (ANOVA), at $\mathrm{p}<0.02$.

\section{RESULTS}

\section{PCR of $T_{1}$ and $T_{2}$ progenies}

Figure 1 shows the results from the two PCR screening rounds using two different pairs of specific primers for each gene. All $\operatorname{Kan}^{\mathrm{R}} \mathrm{T}_{1}$ plants were PCR- ositive while all $\mathrm{Kan}^{\mathrm{S}}$ were negative (Figure 1a). Similar results were obtained from the PCR tests for the 1180 bp fragment, which included the sod gene (Figure 1b). 

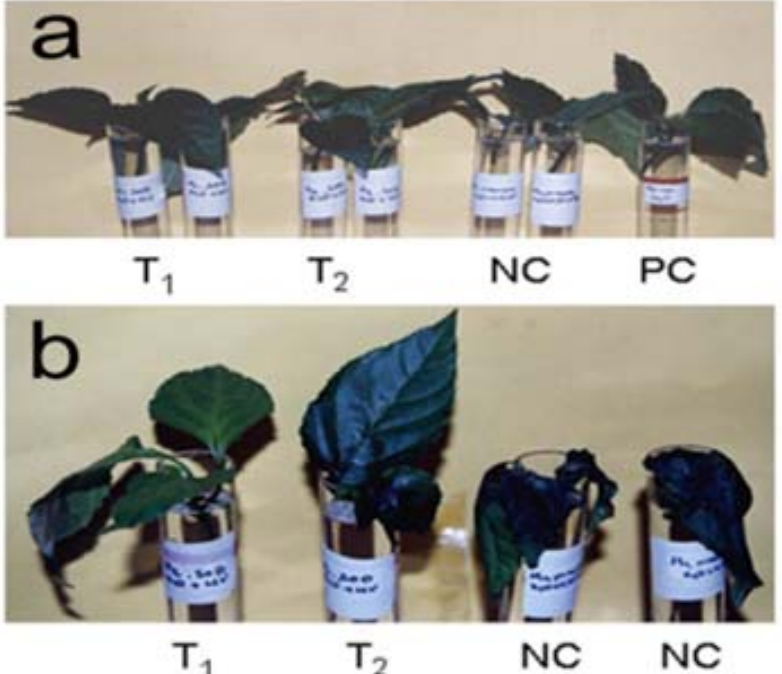

Figure 3. Response of shoots from $T_{1}$ and $T_{2}$ transgenic pepper plants to MV. (a) Stems with fully expanded mature leaves from greenhouse-grown plants were placed in tubes containing $50 \mathrm{ml} 0.25 \times 10^{-3} \mathrm{M} \mathrm{MV}$. (b) $16 \mathrm{hrs}$ after MV shoots were transferred to water and $48 \mathrm{hrs}$ after exposure to constant illumination, they were photographed. $T_{1}, T_{2}$ : transgenic pepper plants; NC: negative control of non-transgenic pepper plant, PC: positive control of transgenic pepper plant in $\mathrm{H}_{2} \mathrm{O}$.

\section{SOD enzymatic activity in $T_{1}$ and $T_{2}$ progenies}

To test the expression of the sod transgene, total protein extracts from leaves of transgenic and control pepper plants were electrophoresed in native polyacrylamide gels. Protein extracts were run on SOD activity gels, together with extracts of tomato plants and control untransformed red pepper type "Florinis" plants. All $\mathrm{T}_{1}$ and $\mathrm{T}_{2}$ plants revealed a "novel" faster moving band at a lower position than the pepper chl $\mathrm{Cu} / \mathrm{Zn}$ SOD bands (Figure 2). This novel band co-migrates at the same molecular weight as the lower tomato band as shown in Figure 2 and could represent a heterodimer enzyme. Obtaining an enzymatic band for a protein encoded by the transgene suggests that the respective gene was not only introduced into the transgenic plants $\left(T_{1}\right.$ and $\left.T_{2}\right)$ but it was also functional thus, yielding a functional product.

\section{The effect of $M V$ on $T_{1}$ and $T_{2}$ progenies}

Preliminary experiments with untransformed pepper plants indicated that $0.25 \times 10^{-3} \mathrm{M}$ of MV was an appropriate concentration to detect for damages caused by MV to pepper plants. The results presented in Figure 3 demonstrate that $T_{1}$ and $T_{2}$ transgenic pepper plants were less damaged from $0.25 \times 10^{-3} \mathrm{M}$ of MV compared to the control plants (NC) and were phenotypicaly similar to the transgenic plants in water (PC). The untransformed control shoots showed clear paraquat - damage symptoms. The leaves turned chlorotic and then wilted irreversibly. On the contrary, the transgenic $T_{1}$ and $T_{2}$ shoots exhibited only moderate symptoms, compared to the control plants, indicating a positive correlation between over-expressing $\mathrm{Cu} / \mathrm{Zn}$ SOD protein in the chloroplasts and MV tolerance.

\section{The effect of drought-stress on $T_{1}$ and $T_{2}$ progenies}

The oxidative damage can also be quantitatively and statistically assessed by conductivity measurements of electrolyte leakage from leaf tissue. After about two weeks without watering (see Material and Methods for details), untransformed control plants exhibited all the stress symptoms such as permanent wilting, dark - green leaves and retarded growth, whereas $T_{1}$ and $T_{2}$ transgenic plants were less affected. For water stress tolerance, RWC and the leakage of electrolytes were conducted at days 0 and 14 (without watering) compared to normally watered wt and transgenic pepper plants. As shown in Figure 5, on the first
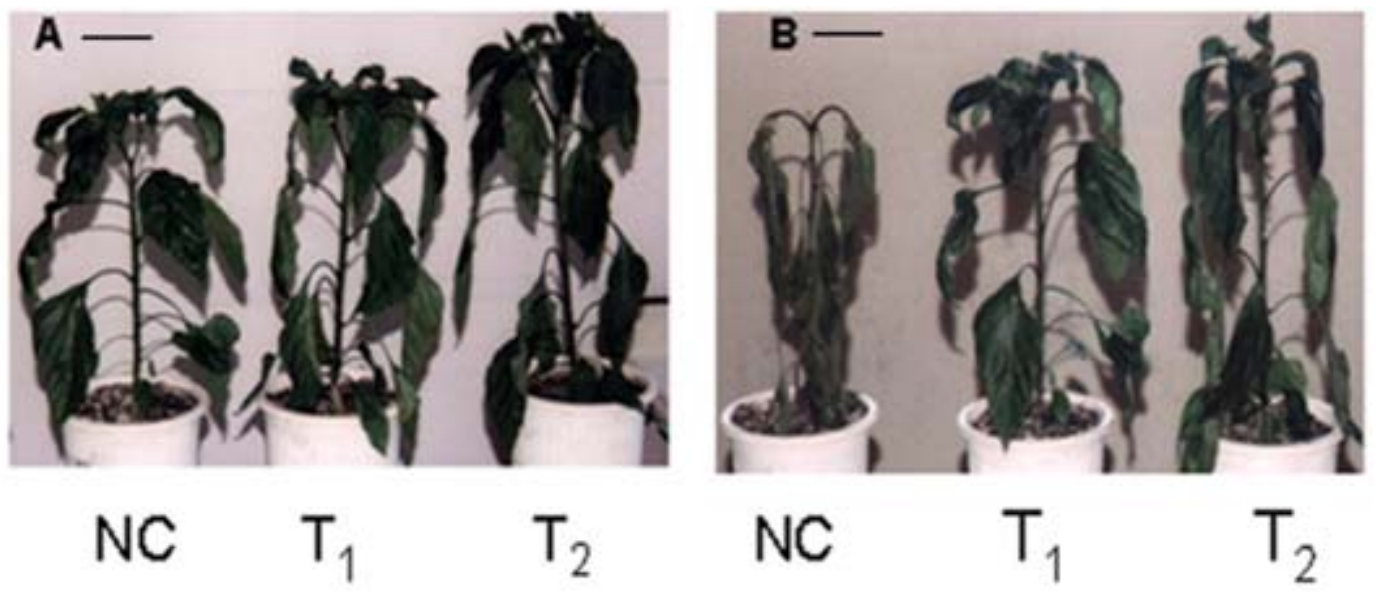

Figure 4. Response of $T_{1}$ and $T_{2}$ transgenic pepper plants to drought stress. (A): First days of water stress. (B): After 14 days without water. NC: negative control of non-transgenic pepper plant:transgenic pepper plants $(\mathrm{bar}=28.6 \mathrm{~mm})$ 


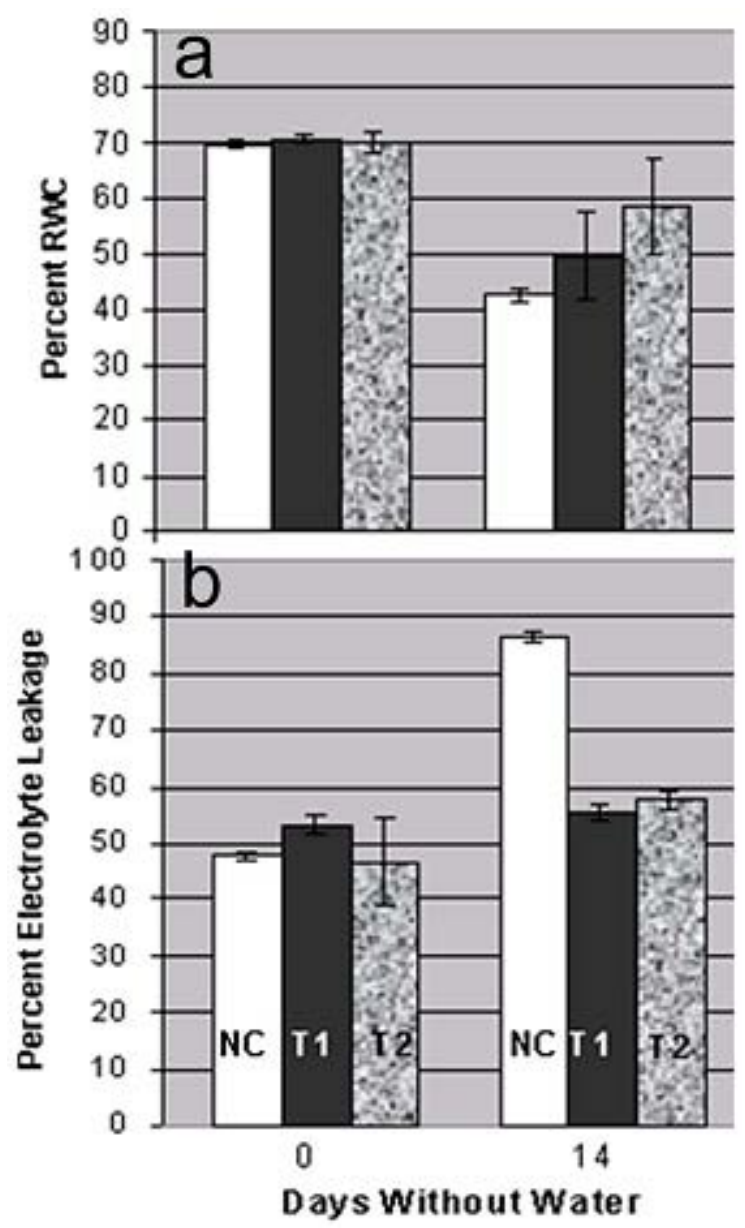

Figure 5. Water-deficit stress. The RWC (a) and the Electrolyte Leakage; (b) were measured from leaves of transgenic and wt pepper plant type "Florinis" at days 0 and 14 without water, using leaf disks from the fifth leaf of each plant. NC: negative control of non - transgenic pepper plant, $\mathrm{T}_{1}$ and $\mathrm{T}_{2}$ : transgenic pepper plants. Values are means of 3 independent plants of the $\mathrm{T}_{1}, \mathrm{~T}_{2}$ generation and untransformed plants similarly treated, $p=0,001$.

day of the experiment there was no statistical difference and no change in RWC (70.57\% and $69.69 \%)$ and the leakage of electrolytes (53.32\% and $43.26 \%$ ) in $\mathrm{T}_{1}$ and $\mathrm{T}_{2}$ transformed plants, as compared to the control ones (69.54\% and $47.65 \%)$.

Under long periods of water stress (14 days), the $T_{1}$ and $T_{2}$ transgenic plants showed reduced leakage $(55.38 \%$ and $57.57 \%)$ and higher RWC (49.78\% and 58.55\%), respectively, compared to the control (86.65 and 42.49). We must note here that the transgenic plants recovered from the water stress while the wt plants showed clear symptoms of water deprivation after 14 days (Figure 5). The control plants showed reduced tolerance to water deficit as shown by the RWC (42.49\%) and a higher percentage of leakage (86.65\%), because the cellular damage reached nearly complete membrane disruption, whereas $T_{1}$ and $T_{2}$ sod transgenic plants exhibited significantly less damage (Figure 4).

The results presented in Figure 5a and Figure 5b suggest that he sod transgenic plants are highly resistant to water stress deficiency as shown by their the physiological response which corresponds to around 1.5 times lower electrolyte leakage compared to the wild type plants (NC).

\section{Regeneration ability}

Shoot regeneration from the hypocotyl explants of three independent $T_{1}$ and three $T_{2}$ transgenic plants and wt was assessed on regeneration medium (Zambounis et al. 2002). The frequency of shoot regeneration and the mean number of regenerated shoots are presented in Figure 6. Statistical analysis of the data (regeneration frequency/mean number) showed statistically significant differences between $\mathrm{T}_{1}(\mathrm{p}<$ $0.02)$ and $T_{2}(p<0.003)$ generations of sod carrying transgenic pepper plants and the wt control plants. Differentiation of shoot buds was observed after 3 weeks of culture and most shoots were formed at the region of the cut. The transgenic plants have statistically significant higher regeneration ability (mean number of shoots) compared to the wt (20) both in the $\mathrm{T}_{1}(29,26,25)$ and $\mathrm{T}_{2}$ $(28,24,27)$ generations (Figure 6$)$. Similarly the transgenic plants have higher regeneration frequency. High percentage (\%) of regeneration frequencies were obtained with the $T_{1}$ (55.33, 58.33, 65.21) and $\mathrm{T}_{2}(53.33,60.00,62.22)$ generations, respectively, as compared to the wt (44.44) (data not shown). Taken together, all independent transgenic plants from two generations have a higher regeneration ability compared to the wt.

\section{DISCUSSION}

Plants possess various mechanisms in order to be protected from reduced oxygen species. Protection against oxidative stress is complex and includes both enzymatic and nonenzymatic components. Key enzyme in the defense mechanism is SOD, which is the first enzyme in the detoxifying process that converts $\mathrm{O}_{2}^{-}$radicals to $\mathrm{H}_{2} \mathrm{O}_{2}$. In some abnormal conditions such as water stress (Synková and Valcke, 2001), drought and freezing stress (Wu et al. 1999; Li et al. 2006; Prashanth et al. 2008), heat stress (Sala and Lafuente, 1999) and preparation of tissue culture (Zheng et al. 2005), reactive oxygen species (ROS) production can be induced, leading to increased SOD and CAT activities in order to decrease the ROS concentration and protect the cell (Zheng et al. 2005). Moreover, ROS can cause oxidation of the cell membrane and destroy its function. Some biological macro-molecules such as chlorophyll, protein and DNA also are oxidized and could lead to plant death in stress conditions.

In this study we investigated $T_{1}$ and $T_{2}$ transgenic pepper plants expressing the sod gene in order to investigate whether they had enhanced resistance to various forms of oxidative stress. 
Molecular data from PCR confirmed that the transgenic plants contained the sod gene (Figure 1). The nptII gene was detected using primers that amplified a 650 bp band, identical to the band amplified from the binary plasmid that was used for the transformation experiments (Figure 1a). $T_{1}$ and $\mathrm{T}_{2}$ transgenic plants from chlCu/Zn SOD constructs which were also confirmed to posses the 35S-SOD-nos fragment (1180 bp) were used for further experiments (Figure 1b).

SOD isozyme patterns of protein extracts from pepper, tomato and transgenic $T_{1}$ and $T_{2}$ pepper plants show that the transgenic plants are expressing the sod gene yielding a functional product. The sod gene is stably inherited from the $T_{1}$ to $T_{2}$ generation where it is also found to be expressed (Figure 2).

Shoots derived from $18 \mathrm{~T}_{1}$ and $\mathrm{T}_{2}$ transformed pepper plants were incubated in $0.25 \times 10^{-3} \mathrm{M}$ of MV. After the MV treatment, the maximum paraquat-damage symptoms were observed in control plants. All $\mathrm{T}_{1}$ and $\mathrm{T}_{2}$ transgenic pepper plants showed increase resistance to oxidative damage by exposure to relatively high concentration of MV. In Figure 3 we show a representative sample of the results obtained from the experiment above. It has been shown that over-expression of $\mathrm{Cu} / \mathrm{Zn}$ SOD in rice leads to increased tolerance to $\mathrm{MV}$ mediated oxidative stress (Prashanth et al. 2008). Also, when SOD was overexpressed in tall fescue plants enhanced resistance to MV was observed (Lee et al. 2007). Moreover, potato plants expressing tomato $\mathrm{Cu} / \mathrm{Zn}$ SOD showed increased $\mathrm{MV}$ tolerance (Perl et al. 1993). Furthermore, expression of Mn SOD from pea leads to enhanced drought tolerance to transgenic rice (Wang et al. 2005).

We have also measured ion leakage, (which reflects membrane damage), after 14 days of water deprivation. We observed an increased ion leakage in the control plants (86.65\%) compared to the transgenic plants were the leakage was significantly reduced, in $\mathrm{T}_{1}$ it was $55.38 \%$ and in $\mathrm{T}_{2} 57.57 \%$ (Figure 5). The membrane damage is attributed partially to oxidative stress, which is a secondary effect of drought stress. The reduction in membrane damage in transgenic plants after the drought treatment is probably caused by an increased SOD activity (Figure 4), which provides higher ROS scavenging efficiency. The increased SOD activity had a similar protective effect against oxidative stress caused by $M V$ when $T_{1}$ and $T_{2}$ transgenic plants were challenged with the herbicide (Figure 3).

Furthermore, we tested whether the SOD expressing plants had increased regeneration ability, for that reason plant regeneration from hypocotyl explants of transgenic and control pepper was established. The transgenic plants T1 $(29,26,25)$ and $\mathrm{T} 2 \quad(28,24 ; 27)$ have statistically significant higher regeneration ability compared to the wt (20) (Figure 6).
The highest regeneration frequencies (\%) were obtained from the transgenic plants $\mathrm{T} 1: 55.33$ to $65.21 \%$ and $\mathrm{T} 2: 53.33$ to $62.22 \%$ compared to the wt were the regeneration was only at $44.44 \%$. All independent transgenic plants from two generations have statistically significant higher regeneration ability compared to the wt.

The last few years it became clear that $\mathrm{H}_{2} \mathrm{O}_{2}$ is not only a damaging agent. The role of $\mathrm{H}_{2} \mathrm{O}_{2}$ as cellular messenger capable of inducing gene expression and protein synthesis has been established (Vranová et al. 2002; Apel and Hirt, 2004). It has been shown that $\mathrm{H}_{2} \mathrm{O}_{2}$ may function as a development signaling molecule in the differentiation of secondary walls in cotton fibers (Apel and Hirt, 2004). Furthermore $\mathrm{H}_{2} \mathrm{O}_{2}$ is a membrane-permeable molecule that has been demonstrated to function as a diffusible intercellular signal (Levine et al. 1994). It is known to induce a number of genes and proteins involved in stress defenses (Scandalios, 2005). Recently, a link has been established between ROS production and plant developmental physiology. High ROS production was observed in the expansion zone of maize leaf and a certain concentration of $\mathrm{H}_{2} \mathrm{O}_{2}$ is necessary for leaf elongation (Rodriguez et al. 2002). The ability of $\mathrm{H}_{2} \mathrm{O}_{2}$ to diffuse through cell membranes and to be naturally produced makes it suitable to act as a signal molecule in cell function (Tian et al. 2003).

Although the role of $\mathrm{H}_{2} \mathrm{O}_{2}$ in somatic embryogenesis is not

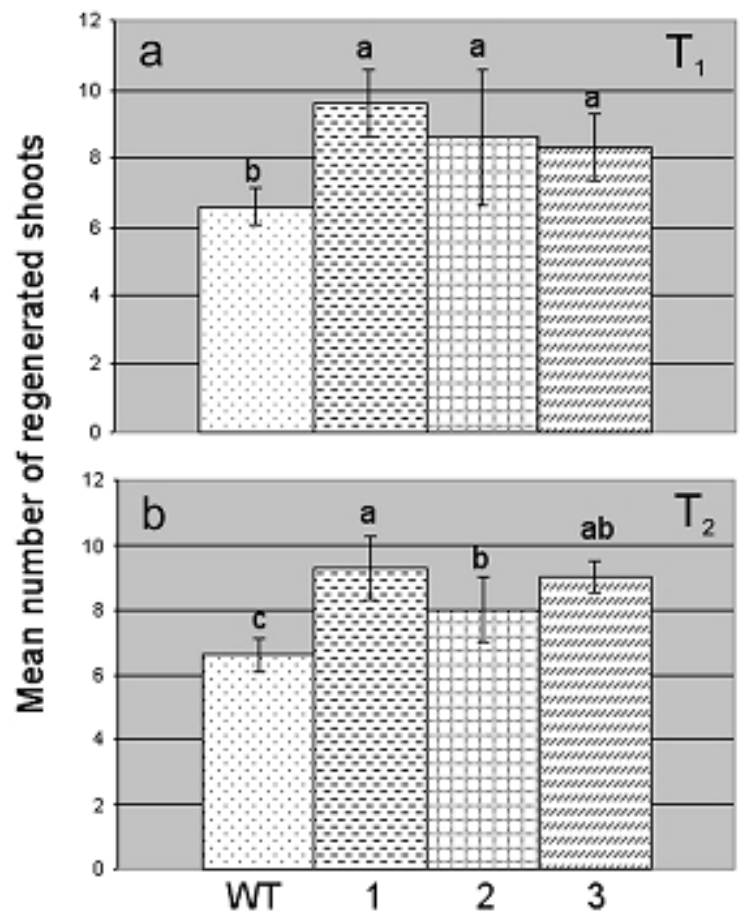

Figure 6. Mean number of regenerated shoots of $T_{1}(a)$ and $\mathrm{T}_{2}$ (b) generations of sod carrying transgenic pepper compared to the control plants (WT), 1-3: $T_{1}$ and $T_{2}$ independent transgenic pepper plants. 
clear, $\mathrm{H}_{2} \mathrm{O}_{2}$ has been considered to serve as secondary messenger to signal stress-induced responses in plants (Van Camp et al. 1998; Neill et al. 2002). Calli with low CAT activity and high $\mathrm{H}_{2} \mathrm{O}_{2}$ concentration displayed a regeneration potential which might support the hypothesis that the $\mathrm{H}_{2} \mathrm{O}_{2}$ produced in excess may promote the expression of some genes responsible for the induction of morphogenesis processes (Libik et al. 2005).

In peanuts (Arachys hypogaea L.) the use of antioxidants enhanced superoxide dismutase (SOD) and catalase (CAT) activities, thus increased the frequency of plant regeneration and transformation efficiency of peanut explants transformed via Agrobacterium tumefaciens (Zheng et al. 2005). Moreover, higher levels of intracellular $\mathrm{H}_{2} \mathrm{O}_{2}$ induce and promote somatic embryogenesis of Lycium barbarum L. callus (Cui et al. 1999). Furthermore during the differentiation and development of callus, SOD activity increased in the early regeneration culture and decreased thereafter and catalase activity constantly declined while peroxidase decreased during the 5 - days culture and gradually increased thereafter. No SOD and low $\mathrm{H}_{2} \mathrm{O}_{2}$ levels were detected in calli possessing low organogenesis capacity, suggesting that $\mathrm{H}_{2} \mathrm{O}_{2}$ is correlated with the morphogenetic process in strawberry callus and may actually serve as a messenger in the process of bud primordium formation (Tian et al. 2003). Gupta and Datta (2003) reported that the activity of SOD gradually increased during somatic embryogenesis and peaked when the somatic embryos were detected, while activities of catalase (CAT) and peroxidase (POX) decreased. In addition, recent research suggests that suppressed expression of totipotency in tobacco protoplasts was correlated with reduced activity of cellular antioxidant machinery (SOD) (Papadakis et al. 2001). In Lycium barbarrum (Cui et al. 1999) and Astragalus adsurgens (Luo et al. 2001) somatic embryogenesis can be enhanced by exogenous application of $\mathrm{H}_{2} \mathrm{O}_{2}$ or inhibition of $\mathrm{H}_{2} \mathrm{O}_{2}$ degrading enzymes such as catalase and ascorbate peroxidase.

Pepper is a recalcitrant species, so a line with enhanced regeneration efficiency could facilitate and increase the transformation efficiency of pepper. Pepper fruit could be useful as they could be used for the production of high valuable products, like oral vaccines. The results reported here where transgenic pepper plants over-expressing a tomato $\mathrm{Cu} / \mathrm{Zn}$ SOD showed increased regeneration efficiency supports the hypothesis that $\mathrm{H}_{2} \mathrm{O}_{2}$ may play a role in plant morphogenesis.

\section{ACKNOWLEDGEMENTS}

Dr. Fotini Milona from NAGREF for her help with SOD gel analysis.

\section{REFERENCES}

APEL, Klaus and HIRT, Heribert. Reactive oxygen species: Metabolism, oxidative stress, and signal transduction. Annual Review of Plant Biology, June 2004, vol. 55, no. p. 373-399.

BADAWI, Ghazi Hamid; YAMAUCHI, Yasuo; SHIMADA, Emi.; SASAKI, Ryozo; KAWANO, Naoyoshi; TANAKA, Kunisuke and TANAKA, Kiyoshi. Enhanced tolerance to salt stress and water deficit by overexpressing superoxide dismutase in tobacco (Nicotiana tabacum) chloroplasts. Plant Science, April 2004, vol. 166, no. 4, p. 919-928.

BEAUCHAMP, Charles and FRIDOVICH, Irwin. Superoxide dismutase: Improved assays and an assay aplicable to acrylamide gels. Analytical Biochemistry, November 1971, vol. 44, no. 1, p. 276-287.

BRADFORD, Marion M. A rapid and sensitive method for quantitation of microgram quantities of protein utilizing principle of protein-dye binding. Analytical Biochemistry, May 1976, vol. 72, no. 1-2, p. 248-254.

CUI, Kairong; XING, Gensheng; LIU, Xinmin; XING, Genmei and WANG, Yafu. Effect of hydrogen peroxide on somatic embryogenesis of Lycium barbarum L. Plant Science, August 1999, vol. 146, no. 1, p. 9-16.

DE MARCO, A. and ROUBELAKIS-ANGELAKIS, K.A. Hydrogen peroxide plays a bivalent role in the regeneration of protoplasts. Journal of Plant Physiology, July 1996, vol. 149, no. 1-2, p. 109-114.

DESIKAN, Radhika; MACKERNESS, Soheila A.H.; HANCOCK, John T. and NEILL, Steven J. Regulation of the Arabidopsis transcriptome by oxidative stress. Plant Physiology, September 2001, vol. 127, no. 1, p. 159-172.

GUPTA, S.D. and DATTA, S. Antioxidant enzyme activities during in vitro morphogenesis of gladiolus and the effect of application of antioxidants on plant regeneration. Biologia Plantarum, September 2003, vol. 47, no. 2, p. 179-183.

LAEMMLI, U.K. Cleavage of structural proteins during assembly of head of bacteriophage-T4. Nature, August 1970, vol. 227, p. 680-685.

LEE, Sang-Hoon; AHSAN, Nagib; LEE, Ki-Won; KIM, Do-Hyun; LEE, Dong-Gi; KWAK, Sang-Soo; KWON, Sook-Yoon; KIM, Tae-Hwan and LEE, Byun Hyun. Simultaneus overexpreession of both $\mathrm{CuZn}$ superoxide dismutase and ascorbate peroxidase in transgenic tall fescue plants confers increased tolerance to a wide range of abiotic stresses. Journal of Plant Physiology, December 2007, vol. 164, no. 12, p. 1626-1638.

LEVINE, Alex; TENHAKEN, Raimund; DIXON, Richard and LAMB, Chris. $\mathrm{H}_{2} \mathrm{O}_{2}$ from the oxidative burst 
orchestrates the plant hypersensitive disease resistance response. Cell, November 1994, vol. 79, no. 4, p. 583-593.

LI, Y.; DENG, X.P.; KWAK, S.S. and TANAKA, K. Drought tolerance of transgenic sweet potato expressing both $\mathrm{Cu} / \mathrm{Zn}$ superoxide dismutase and ascorbate peroxidase. Journal of Plant Physiology and Molecular Biology, 2006, vol. 32, no. 4, p. 451-457.

LIBIK, Marta; KONIECZNY, Robert; PATER, Beata; SLÉSAK, Ireneusz and MISZALSKI, Zbigniew. Differences in the activities of some antioxidant enzymes and in $\mathrm{H}_{2} \mathrm{O}_{2}$ content during rhizogenesis and somatic embryogenesis in callus cultures of the ice plant. Plant Cell Reports, March 2005, vol. 23, no. 12, p. 834-841.

LUO, Jian-Ping; JIANG, Shao-Tong and PAN, Li-Jun. Enhanced somatic embryogenesis by salicylic acid of Astragalus adsurgens Pall.: relationship with $\mathrm{H}_{2} \mathrm{O}_{2}$ production and $\mathrm{H}_{2} \mathrm{O}_{2}$-metabolizing enzyme activities. Plant Science, June 2001, vol. 161, no. 1, p. 125-132.

MANCINI, Andrea; BUSCHINI, Anna Maria; RESTIVO, Francesco Maria; ROSSI, Carlo and POLI, Paola. Oxidative stress as DNA damage in different transgenic tobacco plants. Plant Science, April 2006, vol. 170, no. 4, p. $845-852$.

MURASHIGE, Toshio and SKOOG, Folke. A revised medium for rapid growth and bio assays with tobacco tissue cultures. Physiologia Plantarum, July 1962, vol. 15, no. 3, p. 473-497.

NEILL, Steven J.; DESIKAN, Radhika; CLARKE, Andrew; HURST, Roger D. and HANCOCK, John T. Hydrogen peroxide and nitric oxide as signaling molecules in plants. Journal of Experimental Botany, May 2002, vol. 53, no. 372, p. 1237-1247.

PAPADAKIS, Anastasia K.; SIMINIS, Charalambos I. and ROUBELAKIS-ANGELAKIS, Kalliopi A. Reduced activity of antioxidant machinery is correlated with suppression of totipotency in plant protoplasts. Plant Physiology, May 2001, vol. 126, no. 1, p. 434-444.

PERL, A.; PERL-TREVES, R.; GALILI, S.; AVIV, D.; SHALGI, E.; MALKIN, S. and GALUN, E. Enhanced oxidative-stress defense in transgenic potato expressing tomato $\mathrm{Cu}, \mathrm{Zn}$ superoxide dismutases. Theoretical and Applied Genetics, January 1993, vol. 85, no. 5, p. 568-576.

PERL-TREVES, Rafael and GALUN, Estra. The tomato $\mathrm{Cu}, \mathrm{Zn}$ superoxide-dismutase genes are developmentally regulated and respond to light and stress. Plant Molecular Biology, October 1991, vol. 17, no. 4, p. 745-760.

PRASHANTH, S.R.; SADHASIVAN, V. and PARIDA, A. Over expression of cytosolic copper/zinc superoxide dismutase from a mangrove plant Avicenia marina in indica rice var Pusa Basmati-1 confers abiotic stress tolerance.
Transgenic Research, April 2008, vol. 17, no. 2, p. 281291.

RODRIGUEZ, Andrés A.; GRUNBERG, Karina A. and TALEISNIK, Edith L. Reactive oxygen species in the elongation zone of maize leaves are necessary for leaf extension. Plant Physiology, August 2002, vol. 129, no. 4, p. 1627-1632.

SALA, José M. and LAFUENTE, María T. Catalase in the heat-induced chilling tolerance of cold-stored hybrid Fortune mandarin fruits. Journal of Agricultural and Food Chemistry, June 1999, vol. 47, no. 6, p. 2410-2414.

SCANDALIOS, J.G. Oxidative stress: molecular perception and transduction of signals triggering antioxidant gene defenses. Brazilian Journal of Medical and Biological Research, July 2005, vol. 38, no. 7, p. 9951014.

SYNKOVÁ, Helena and VALCKE, Roland. Response to mild water stress in transgenic Pssu-ipt tobacco. Physiologia Plantarum, December 2001, vol. 112, no. 4, p. 513-523.

TERTIVANIDIS, Konstantinos; GOUDOULA, Catherine; VASILIKIOTIS, Christos; HASSIOTOU, Efthymia; PERL-TREVES, Rafael and TSAFTARIS, Athanasios. Superoxide dismutase transgenes in sugarbeets confer resistance to oxidative agents and the fungus $C$. beticola. Transgenic Research, June 2004, vol. 13, no. 3, p. 225-233.

TIAN, Min; GU, Qing and ZHU, Muyuan. The involvement of hydrogen peroxide and antioxidant enzymes in the process of shoot organogenesis of strawberry callus. Plant Science, October 2003, vol. 165, no. 4, p. 701-707.

VAN CAMP, Wim; VAN MONTAGU, Marc and INZÉ, Dirk. $\mathrm{H}_{2} \mathrm{O}_{2}$ and NO: redox signals in disease resistance. Trends in Plant Science, September 1998, vol. 3, no. 9, p. 330-334.

VRANOVÁ, Eva; ATICHARTPONGKUL, Sopapan; VILLAROEL, Raimundo; VAN MONTAGU, Marc; INZÉ, Dirk and VAN CAMP, Wim. Comprehensive analysis of gene expression in Nicotiana tabacum leaves acclimated to oxedative stress. Proccedings of the National Academy of Sciences of the United States of America, August 2002, vol. 99, no. 16, p. 10870-10875.

WANG, Fang-Zheng; WANG, Qing-Bin; KWON, SukYoon; KWAK, Sang-Soo and SU, Wei-Ai. Enhanced drought tolerance of transgenic rice plants expressing a pea manganese superoxide dismutase. Journal of Plant Physiology, April 2005, vol. 162, no. 4, p. 465-472.

WU, Guohai H.; WILEN, Ronald W.; ROBERTSON, Albert J. and GUSTA, Lawrence V. Isolation, chromosomal localization, and differential expression of mitochondrial manganese superoxide dismutase and 
chloroplastic Copper / Zinc superoxide dismutase genes in wheat. Plant Physiology, June 1999, vol. 120, no. 2, p. 513520 .

ZAMBOUNIS, Antonios; NIANIOU-OBEIDANT, Irini and TSAFTARIS, Athanasios. Cloning of superoxide dismutase $(\mathrm{Cu} / \mathrm{Zn} \mathrm{SOD})$ gene in peppers for stress tolerance. II Balkan Symposium on Vegetables and Potatoes. Acta Horticulturae, 2002, vol. 579, p. 101-106.

ZHENG, Qiusheng; BAO, Ju; LIANG, Likun K. and Xiao, Xinhua. Effects of antioxidants on the plant regeneration and GUS expressive frequency of peanut (Arachis hypogaea) explants by Agrobacterium tumefaciens. Plant Cell Tissue and Organ Culture, April 2005, vol. 81, no. 1, p. 83-90. 